\title{
外来入侵植物对本地植物菌根真菌的影响及其机制
}

\author{
唐金琦 ${ }^{1}$ 郭小城 ${ }^{1}$ 鲁新瑜 刘明超 $^{1}$ 张海艳 $^{1}$ 冯玉龙 $^{1^{*}}$ 孔德良 $^{2^{*}}$ \\ ${ }^{1}$ 沈阳农业大学生物科学技术学院, 沈阳 110866 ; ${ }^{2}$ 河南农业大学林学院, 郑州 450002
}

\begin{abstract}
摘 要 菌根真菌共生是植物吸收养分的一个重要策略。外来植物可以干扰本地植物与菌根真菌的共生关系从而抑制本地植 物生长, 这是近年来被发现的一种重要入侵机制, 在研究中得到日益广泛的关注。该文从以下几个方面着重综述这种入侵机 制: 1)外来植物对本地植物菌根真菌的影响, 包括菌根真菌侵染率、菌根内部结构、根外菌丝的量、菌根真菌的群落组成、 非菌根真菌的影响及网络结构; 2)外来植物对本地植物菌根真菌上述影响的机制，包括资源竞争、化感作用和土壤肥力等生 态机制以及相关的分子机制; 3)上述两个方面随入侵时间的变化格局。尽管干扰本地植物菌根真菌是一种重要的入侵机制, 但相对其他的入侵机制(例如天敌逃逸、新武器假说等)来说，这类机制的研究目前仍很圄乏。鉴于此，该文提出了未来需要 重点关注的几个方面: 1)全球变化背景下, 入侵植物对本地植物菌根真菌的影响如何变化; 2)包括这种菌根机制在内的多种入 侵机制之间的关系; 3)深入探究入侵的这种菌根机制在大的时空尺度上的变化规律。
\end{abstract}

关键词 入侵植物; 本地植物; 菌根真菌; 机制; 植物-土壤反馈

唐金琦, 郭小城, 鲁新瑜, 刘明超, 张海䎦, 冯玉龙, 孔德良 (2020). 外来入侵植物对本地植物菌根真菌的影响及其机制. 植物生态学报, 44 , 1095-1112. DOI: $10.17521 /$ cjpe.2020.0166

\section{A review on the effects of invasive plants on mycorrhizal fungi of native plants and their underlying mechanisms}

TANG Jin-Qi ${ }^{1}$, GUO Xiao-Cheng ${ }^{1}$, LU Xin-Yu ${ }^{1}$, LIU Ming-Chao ${ }^{1}$, ZHANG Hai-Yan ${ }^{1}$, FENG Yu-Long ${ }^{1 *}$, and KONG De-Liang ${ }^{2 *}$

${ }^{1}$ College of Bioscience and Biotechnology, Shenyang Agricultural University, Shenyang 110866, China; and ${ }^{2}$ College of Forestry, Henan Agricultural University, Zhengzhou 450002, China

\section{Abstract}

Mycorrhizal fungi symbiosis is an important strategy for plant to uptake soil nutrients. Alien plants could thwart the symbiotic relationship between native plants and mycorrhizal fungus, and thus suppress the growth of native plants, which is an important mechanism for alien plant invasion, and has been increasingly emphasized in recent studies. In the present review, we summarized several key aspects of such mycorrhizal-related mechanism of plant invasion: 1) the impacts of alien plants on mycorrhizal fungi of native plants (i.e. mycorrhizal colonization rate, internal structures of mycorrhizal hyphae, amount of external hyphae, mycorrhizal and non-mycorrhizal composition, and mycorrhizal network); 2) mechanisms of alien-plant impacts on mycorrhizal fungi of native plants, including ecological mechanisms such as resource competition, allelopathy and edaphic fertility, as well as their molecular mechanisms; 3) variations of the above mentioned alien-plant impacts and related mechanisms at different durations of plant invasion. Despite thwarting mycorrhizal fungi of native plants is an important mechanism for alien plant invasion, researches on such mechanism are still scarce comparing to other mechanisms such as natural enemy release and new weapon hypothesis. Therefore, we proposal several research areas that need to be focused on in future studies: 1) how do global changes affect the alien-plant-invasion impacts on mycorrhizal fungi of native plants; 2) what are the relationships among different mechanisms including the mycorrhizal-related mechanism; 3) how does the mycorrhizae-related mechanism change at large spatio-temporal scales.

Key words invasive plant; native plant; mycorrhizal fungi; mechanism; plant-soil feedback

收稿日期Received: 2020-05-25 接受日期Accepted: 2020-07-14

基金项目: 国家自然科学基金(31870522、31670550和31971557)，辽宁省高等学校创新人才支持计划(LR2016048)和国家重点研发计划 (2017YFC1200101)。Supported by the National Natural Science Foundation of China (31870522, 31670550 and 31971557), the Liaoning Provincial Colleges and Universities Innovative Talents Support Program (LR2016048), and the National Key R\&D Program of China (2017YFC1200101).

* 通信作者Corresponding author (Feng YL: fyl@syau.edu.cn; Kong DL: deliangkong1999@126.com) 
Tang JQ, Guo XC, Lu XY, Liu MC, Zhang HY, Feng YL, Kong DL (2020). A review on the effects of invasive plants on mycorrhizal fungi of native plants and their underlying mechanisms. Chinese Journal of Plant Ecology, 44, 1095-1112. DOI: $10.17521 /$ cjpe. 2020.0166

随着全球社会经济活动的日益紧密, 越来越多 的植物被带入非原产地环境, 快速扩散成为入侵植 物。全球变化背景下, 入侵植物已对当地生物多样 性、社会经济以及人类健康造成重大威胁(万方浩等, 2011; 鞠瑞亭等, 2012; van Kleunen et al., 2015; Pathak et al., 2019)。探求外来植物成功入侵的机制 是近几十年来生态和进化领域的一个重要议题, 同 时也是进行入侵防控的前提(Wolfe et al., 2008; Catford et al., 2009; Lau \& Schultheis, 2015; Wan et $a l ., 2019)$ 。外来植物可以通过多种途径成功入侵当 地生态系统(Catford et al., 2009)。例如, 在入侵地由 于缺乏有效天敌，入侵种可以将原来分配到天敌防 御上的资源(如碳和氮)用于生长繁殖而促进入侵 (Blossey \& Notzold, 1995; Feng et al., 2009; Zhao et al., 2020); 入侵种也会具有较高的表型可塑性, 能 更好地适应环境资源的波动(Richards et al., 2006); 它们还会产生一些特殊的化感物质, 抑制本地植物 生长(Callaway et al., 2008; Zheng et al., 2015)。

除了这些被广泛关注的途径, 近年来还发现一 类重要的间接途径, 即入侵植物能通过干扰本地物 种的共生关系(如植物-传粉昆虫和根系-菌根真菌等) 而抑制本地植物的生长(Mitchell et al., 2006; Pringle et al., 2009; 张桂花等, 2009; Wilson et al., 2012)。陆 地生态系统中 $80 \%$ 以上的植物都与菌根真菌共生, 这是陆地上最古老和最重要的共生关系之一(Martin et al., 2017; Brundrett \& Tedersoo, 2018; Steidinger et al., 2019; Tedersoo et al., 2020)。在这种共生 关系中, 植物为菌根真菌提供碳源, 菌根真菌为宿 主植物提供稀缺养分(如磷和氮等), 并帮助宿主防 御病害, 适应胁迫环境( 如干旱和重金属污染 等)(Parniske, 2008; Bonfante \& Genre, 2010; Kohler et al., 2015; Delavaux et al., 2017)。因此, 如果外来 植物能干扰或破坏本地植物根系与菌根真菌的共生 关系, 就可以抑制本地植物生长, 促进自身入侵。近 年来, 一些研究报道了入侵植物这方面的作用(Stinson et al., 2006; Callaway et al., 2008; Vogelsang \& Bever, 2009; Dickie et al., 2017), 表明对本地植物 共生菌根真菌的干扰是外来植物一种重要的入侵 机制。
本文围绕入侵植物对本地植物菌根真菌的影响 和机制, 综述近年来国内外在这方面的进展, 并做 了相关的评论和展望。我们首先分析入侵植物对本 地植物菌根真菌侵染程度、菌根内部结构、根外菌 丝特征、真菌群落组成及真菌网络的影响; 之后综 合分析这些影响背后的生态和分子机制, 涉及资源 竞争、土壤养分、化感作用、信号识别及转导等; 最 后探讨外来植物入侵时间或强度的效应。

\section{1 入侵植物对本地植物菌根真菌的影响}

\section{1 本地植物菌根真菌侵染程度}

早在21世纪初, Stinson等(2006)就注意到了外 来入侵植物对本地植物菌根真菌侵染的影响。他们 发现在原产地欧洲, 苟芥(Alliaria petiolata)对其邻 近植物菌根真菌侵染率的影响不显著; 但在入侵地 北美显著降低了本地植物Acer saccharum、红枫 (Acer rubrum)和Fraxinus americana 丛枝菌根真菌 (AMF)的侵染率，下降幅度分别是 $30 \% 、 14 \%$ 和 $42 \%$ (Stinson et al., 2006; Callaway et al., 2008)。Stinson 等(2006)的研究引起了广泛关注, 他们的工作被认 为是一种潜在的外来植物入侵的新机制。之后人们 选取不同的入侵植物和本地植物体系来检验这种入 侵机制的广泛性。例如，生长在英国的本地植物长 叶车前(Plantago lanceolata)、百脉根(Lotus corniculatus)和红车轴草(Trifolium pratense)也会受 到入侵植物类似的影响, 在虎杖(Fallopia japonica) 入侵时菌根真菌侵染率分别下降了 $20 \% 、 24 \%$ 和 $20 \%$, 而外来植物风仙花(Impatiens glandulifera)对本地植 物侵染率抑制程度弱一些，下降幅度分别为 $12 \%$ 、 11\%和 19\% (Tanner \& Gange，2013)。狗牙根 (Cynodon dactylon)的入侵使匈牙利的小花蝇子草 (Stipa borysthenica)的AMF侵染率降低25\% (Endresz et al., 2013)。在我们检索到的国内外32篇相关文献 中(AMF文献有 27 篇), 有 $44 \%$ 的文献报道入侵植物 显著降低了本地植物AMF侵染率(降低 $18.9 \%$ ), 也 有一少部分文献报道本地植物AMF侵染率未有变 化甚至是增加的现象(增加9.5\%)(表1)。例如，海岸 松(Pinus pinaster)和绢毛荣桦(Hakea sericea)入侵到 夏威夷后当地植物群落的 AMF侵染率均未发生改 


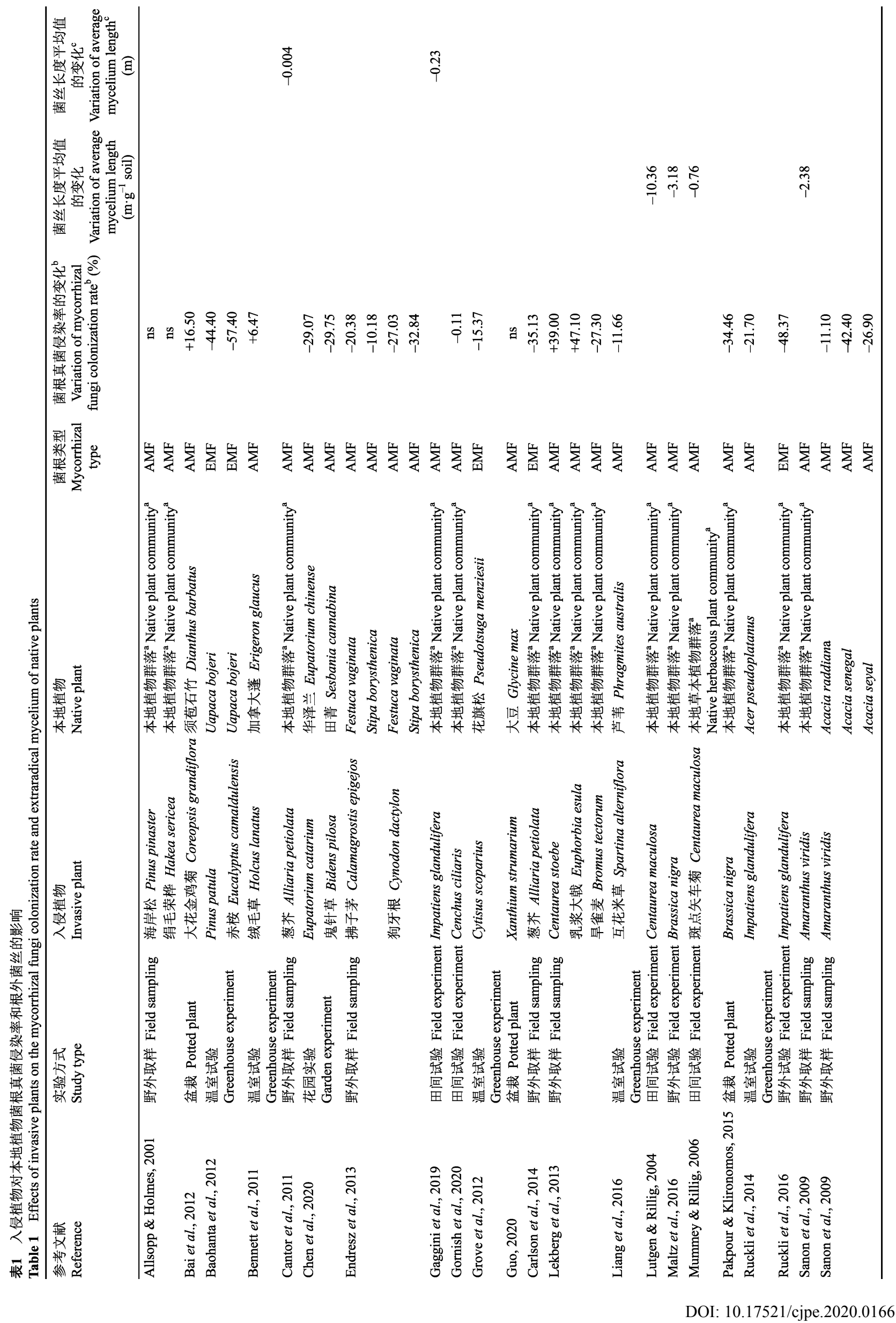




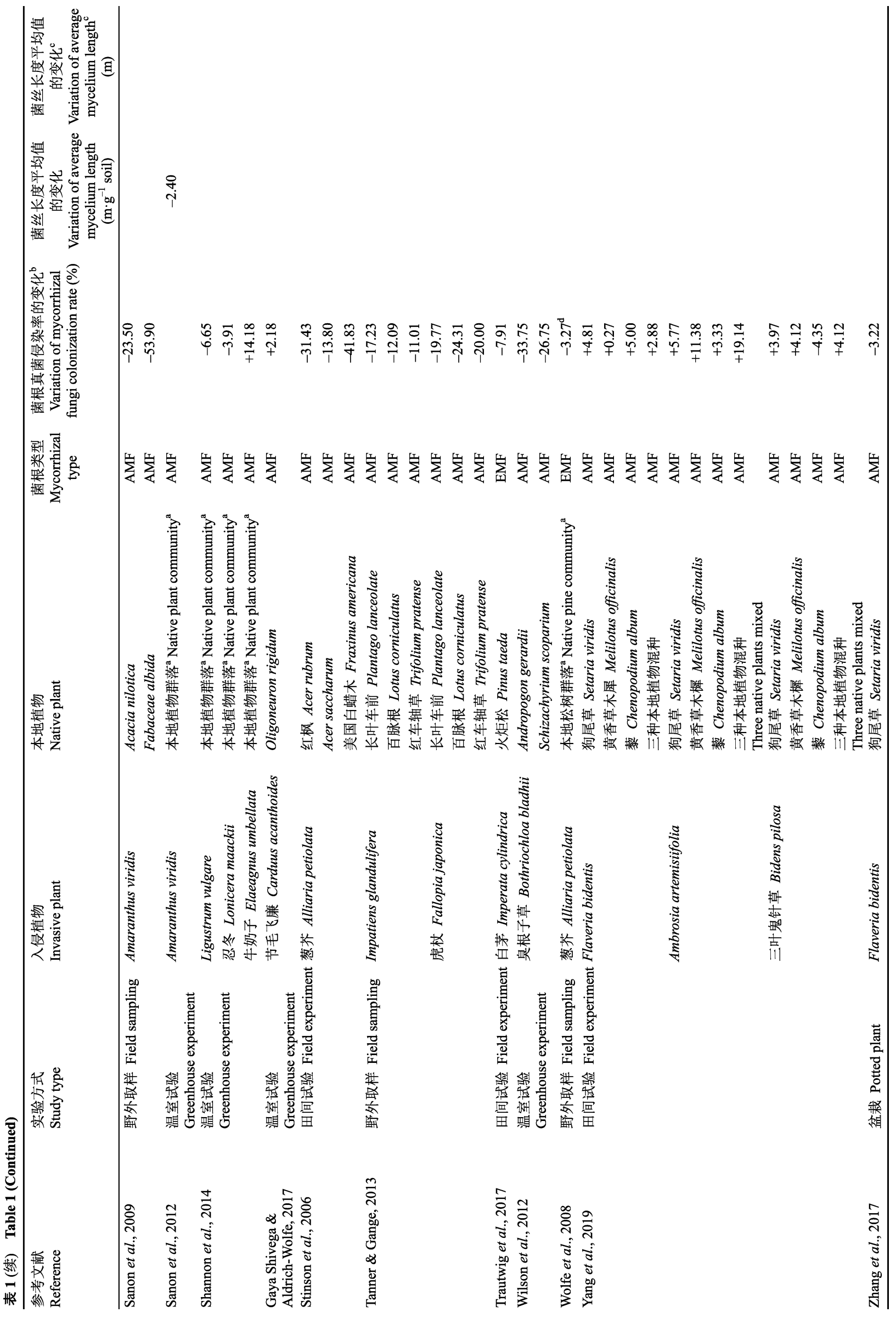



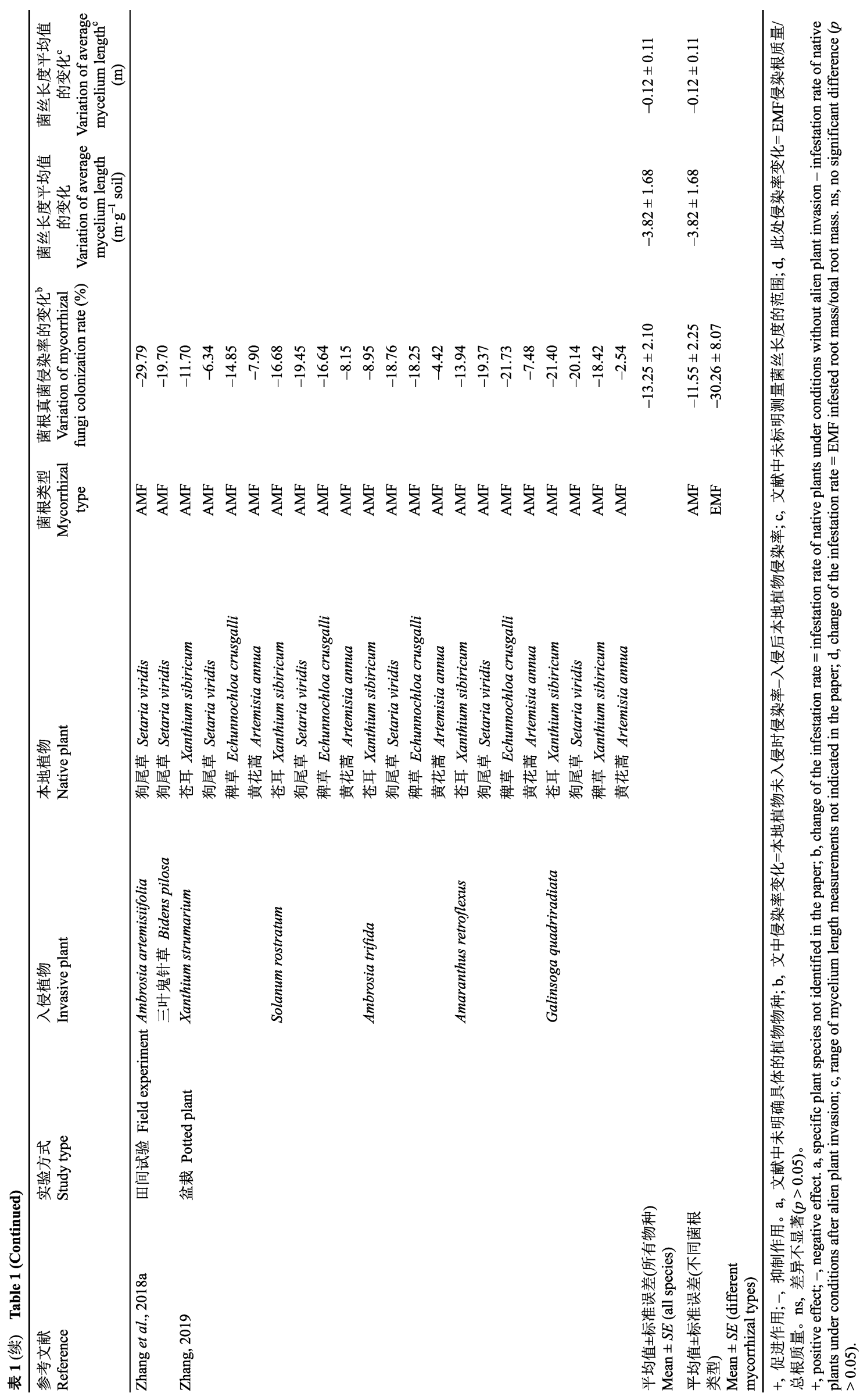

DOI: $10.17521 /$ cjpe. 2020.0166 
变(Allsopp \& Holmes, 2001); 而乳浆大戟(Euphorbia esula) 的入侵使本地植物 $\mathrm{AMF}$ 侵染率由原来的 $40 \%$ 提高到 $79 \%$, 入侵植物Centaurea stoebe使本地 植物侵染率提升了1.2倍(Lekberg et al., 2013)。

相对于AMF，外生菌根真菌(EMF)对外来干扰 的抵抗能力更强(Chen et al., 2020), 但研究表明外 来入侵植物能抑制本地植物EMF的侵染程度(Wolfe et al., 2008)。例如, 葱芥入侵后本地植物群落(红松 (Pinus resinosa)和白松(Pinus strobus))的EMF侵染 率降低约 $75 \%$ (Carlson et al., 2014)。我们整理搜集 文献的相关数据发现, 入侵植物对EMF侵染率平均 降低 $30 \%$, 相对高于入侵植物对AMF的平均抑制程 度 $(11.6 \%)($ 表1)。这表明菌根类型是影响入侵植物对 本地植物菌根真菌干扰程度的重要因素。不过, 我 们也注意到, 相比于 AMF, 涉及入侵植物对本地植 物EMF共生关系影响的研究较少。Grove等(2017a) 综述的 112 篇相关文章中, $82 \%$ 的文章阐述了入侵植 物对本地AMF植物的影响, 只有 $18 \%$ 的文章探讨了 入侵植物对本地EMF植物的影响, 而且这种影响的 程度在不同研究中有较大的差异。因此, 未来需要 扩大对EMF植物的关注, 以检验入侵植物对本地植 物EMF的抑制效果是否普遍高于对本地植物 $\mathrm{AMF}$ 的抑制性。截至目前, 除AMF和EMF这两种常见的 菌根类型外, 我们还未见到入侵植物对其他一些生 长在特殊环境中的重要菌根类型, 如杜鹃类菌根 $(\mathrm{ERM}) 、$ 兰科菌根(ORM)等影响的报道。这可能是 由于这些菌根类型生长在特殊的环境中, 例如杜鹃 花科植物多生长于土壤贫㾑和干旱等恶劣环境中, 外来植物很难成功入侵到类似环境; 而兰科植物是 常见的观赏花卉, 入侵植物在其生存环境中经常被 园艺工人拔除, 导致研究者们忽略了入侵生物的存 在。因此, 未来研究需要探讨不同菌根类型对入侵 植物响应的差异和机制。

尽管入侵植物对本地植物菌根真菌影响的这些 差异性被报道, 但是很少有研究者关注这些差异背 后的原因。我们推测这可能至少与以下几个方面的 原因有关: 1)本地植物和菌根真菌共生关系的强弱。 例如, 有两个本地植物 $\mathrm{A}$ 和 $\mathrm{B}$, 如果 $\mathrm{A}$ 的菌根真菌侵 染率远高于 $\mathrm{B}$ (或者说 $\mathrm{A}$ 对菌根真菌的依赖性远超过 B)(Eissenstat et al., 2015; Bergmann et al., 2020), 那 么入侵植物对 $\mathrm{A}$ 的菌根真菌侵染率的影响要超过 $\mathrm{B}$ 。 2)入侵植物的竞争力和化感作用的大小。例如, 张
海艳(2019)研究发现竞争力较强的入侵种(Xanthium strumarium、Solanum rostratum、Ambrosia trifida、 Amaranthus retroflexus和Galinsoga quadriradiata)对 本地植物苍耳(Xanthium sibiricum)菌根真菌的影响 反而较小, 这可能是由于入侵种的化感物质较弱。

3)土壤养分的高低。例如, 张海艳(2019)研究发现入 侵植物S. rostratum在低养分的情况下对本地植物菌 根真菌的影响更显著, 这可能是低养分情况下本地 植物的菌根真菌对入侵植物的竞争力和化感作用更 敏感所致。

以往研究大多只关注具有单共生关系的本地植 物(只受菌根真菌侵染), 而对具有双共生关系的本 地植物(根瘤菌和AMF共同侵染, 如豆科植物)的研 究很少。我们团队的研究发现, 入侵植物 $X$. strumarium 抑制了本地植物苍耳(单共生关系)的 AMF侵染率(张海艳, 2019), 但没有改变本地植物 大豆(Glycine max)(双共生关系)的AMF侵染率(郭小 城, 2020)。这可能是物种本身的差异所致, 但也不 排除根瘤的存在改变了菌根真菌对入侵植物的响应, 需要进一步研究。这里只涉及一种豆科植物, 我们 还不清楚别的豆科植物以及其他双共生体系中菌根 真菌对外来入侵植物的响应是否有差异。

\section{2 本地植物菌根内部结构和功能}

外来植物入侵后, 本地植物菌根真菌侵染率有 时没有受到显著影响(Allison et al., 2006), 但这并 不等于外来入侵植物不影响本地植物与菌根真菌的 共生关系, 菌根的内部结构和功能可能发生了显著 变化。从枝菌根内部存在多种结构, 包括泡囊、丛 枝、菌丝环以及根内菌丝(图1)。这些不同真菌结构 具有不同的功能, 例如泡囊可以存储真菌脂质及其 他成分, 丛枝和菌丝环是植物与菌根真菌之间进行 碳和养分交换的部位, 根内菌丝可以帮助真菌在根 内定殖并在菌丝内部运输养分(Johnson et al., 2003; Smith \& Read, 2008)。菌根真菌的这些内部侵染结 构会受到环境的影响。Lugli等(2019)研究表明, 土 壤中磷的多少会改变从枝菌根内部结构, 进而影响 菌根功能。入侵植物可以提高入侵地的土壤养分含 量(Pattison et al., 2016; Zhang et al., 2018a), 例如 Liao等(2008)的meta分析表明, 入侵植物可以使入 侵地的土壤养分平均增加 $30 \%$ 。入侵地土壤养分的 提升可能会导致本地植物菌根真菌侵染的改变, 包 括侵染率和菌根内部结构两个方面。然而, 目前有

www.plant-ecology.com 


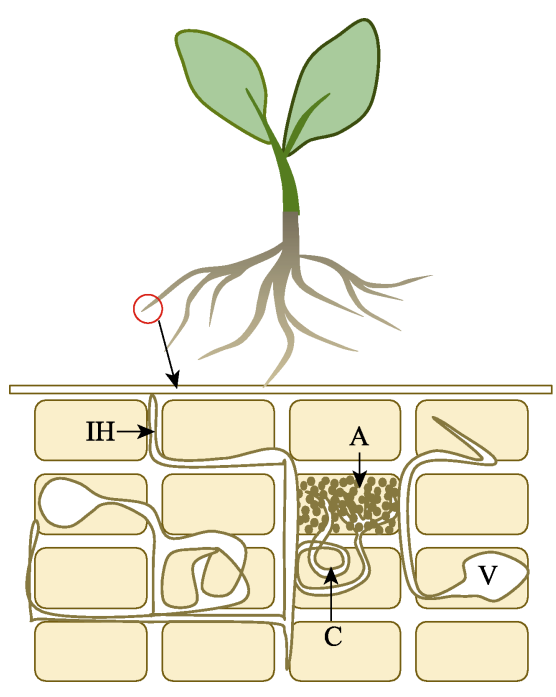

图1 从枝菌根内部结构概念图(改自Johnson等(2003))。A, 从枝; C，菌丝环; IH，根内菌丝; V，泡囊。

Fig. 1 A conceptual diagram of the internal structures of arbuscular mycorrhizae in root tissues (adapted from Johnson et al., 2003). A, arbuscules; C, coils; IH, intraradical hyphae; V, vesicles.

关外来入侵植物对本地植物菌根真菌内部结构影响 的研究很少, 在未来研究中需要加强。

\section{3 本地植物根外菌丝特征}

菌根的根内菌丝延伸至根外形成根外菌丝，根 外菌丝直接参与土壤养分的吸收。外来入侵植物在 对本地植物菌根真菌侵染率、真菌内部结构产生影 响的同时, 也会对根外菌丝产生影响 (Lutgen \& Rillig, 2004; Luo et al., 2019)(表1)。例如, Mummey 和 Rillig (2006) 研究发现, 外来植物斑点矢车菊 (Centaurea maculosa) 的入侵使本地植物的 $\mathrm{AMF}$ 根 外菌丝长度降低24\%; Gaggini等(2019)发现，凤仙花 入侵一年使本地植物根外 $\mathrm{AMF}$ 菌丝生物量降低 $30 \%-80 \%$ 。总体来说, 相对于菌根真菌侵染率, 有 关根外菌丝特征对入侵植物响应的研究较少, 且相 关研究中对根外菌丝的量化标准也不统一, 有的使 用菌丝长度, 有的则使用菌丝生物量, 不利于将来 进行整合分析。我们推荐使用菌丝长度这一指标, 因为其易于测定且成本低。入侵植物除了影响本地 植物根外菌丝的长度和生物量外, 还可能会进一步 影响根外菌丝与吸收功能密切相关的一些生理特 征。例如, 1)根外菌丝分泌蛋白水解酶的能力, 这些 水解酶往往参与分解土壤有机质和生物残体, 释放 其中的养分(Martin et al., 2008; Zhang et al., 2019)。

2)转运蛋白将土壤养分转运至菌丝内的效率 (Bonfante \& Genre, 2010; 田否等, 2016; Jiang et al.,
2017; Zhang et al., 2018b)。

\section{4 本地植物菌根真菌群落组成}

入侵植物除了影响本地植物菌根真菌的侵染 率、根内和根外菌丝的结构与功能外, 还可能改变 其菌根真菌的组成。有研究发现, 外来植物入侵会 使本地植物原有的 $\mathrm{AMF}$ 被其他种类的 $\mathrm{AMF}$ 替代 (Hawkes et al., 2006; Barto et al., 2011; Jordan et al., 2011)，或有部分AMF被替代(Burke，2008)。Zhang 等(2018c)研究发现, 外来入侵植物提高了本地植物 根际土微生物群落中AMF所占比例, 这可能会提高 本地植物菌根真菌中AMF比例。但也有研究发现, 外来植物入侵未改变本地植物的菌根真菌群落组成 (Koch et al., 2011; Meinhardt \& Gehring, 2012), 如 凤仙花入侵一年后本地植物菌根真菌组成未发生变 化(Gaggini et al., 2018)。张海艳(2019)研究发现, 一 方面同一本地植物菌根真菌群落组成对不同入侵植 物的响应不一致, 如入侵植物X. strumarium改变了 黄花蒿根内菌根真菌群落组成, 而入侵植物 $S$. rostratum则没有影响; 另一方面同一入侵植物对不 同本地植物菌根真菌群落组成的影响也不一致, 如 入侵植物X. strumarium改变了黄花蒿的菌根真菌群 落组成, 但未改变本地植物狗尾草的菌根真菌群落 组成。这表明本地植物菌根真菌群落组成对入侵植 物的响应既与本地植物自身特性有关, 也与入侵植 物种类有关。但目前有关入侵植物对本地植物菌根 真菌群落组成影响的研究大多数集中在AMF植物, 我们对本地植物EMF和其他类型菌根真菌群落组 成如何响应入侵植物的认识十分有限。

上述这些研究中, 本地植物菌根真菌群落组成 都是通过变性梯度凝胶电泳(DGGE)(肖龙敏, 2018)、磷脂脂肪酸(PLFA)(席浩, 2019)和高通量测 序(蒋玉玲等, 2019)等方法测定的。除此之外, 菌根 真菌也可以按照其功能进行分类。例如, Kiers等 (2011)将菌根真菌分为合作型真菌和寡合作型真菌, 合作型真菌Glomus intraradices对宿主的养分回报 效率(真菌转运给植物的养分/真菌接受植物的碳之 比)高于葟合作型真菌Glomus aggregatum。由于合作 型真菌对宿主具有更高的养分回报率, 我们推测共 生真菌中以合作型真菌为主的本地植物可能受外来 植物的影响更大。尽管这种推测有待验证, 但我们 认为这种基于真菌功能的真菌群落组成研究是未来 研究中值得关注的一个方向, 这将有助于我们深入 
了解入侵植物对菌根真菌的影响及外来植物入侵机 制。

\section{5 本地植物菌根真菌网络}

同种植物常常能与多种菌根真菌共生, 即使是 单个根尖也往往被多个特定的菌根真菌类群侵染 (Sepp et al., 2019)。这些菌根真菌之间由于不同强度 和方向(包括正和负)的相互作用形成复杂的菌根真 菌网络, 该网络的连接性、模块性往往用来评判真 菌网络结构的稳定性(图2)(Bennett et al., 2013; de Vries \& Wallenstein, 2017)。Sepp等(2019)将植物分 为专性菌根植物 (只依赖菌根吸收养分)和兼性菌根 植物(除菌根外还通过其他方式吸收养分, 如豆科 植物的根瘤), 他们发现专性菌根植物真菌网络的 连接性更强。理论上, 不同的菌根真菌可能构成不 同的网络结构, 而相同的菌根真菌群落组成也可能 构成不同的网络结构。目前研究者往往关注胁迫环 境对菌根真菌网络的影响以及同一环境下不同菌根 类型的真菌网络之间的差异(Toju et al., 2018; 杨思 琪等, 2019)。例如, de Vires等(2018)发现, 干旱情况 下真菌共生网络的复杂性和稳定性均有所降低; 在 AMF和EMF植物共存的系统中, AMF网络与宿主植 物的连接性更强, EMF网络与宿主植物的专一性(共 生伙伴偏好性)更强(杨思琪等, 2019)。菌根真菌网络 的研究方兴未艾, 而菌根真菌网络对入侵植物响应 的研究尚属空白。由于入侵植物会显著改变本地植 物菌根真菌的组成和相对多度(Zhang et al., 2018c; 张海艳, 2019), 我们推断这些都会影响到真菌网络 的连接性和模块性; 由于EMF对环境干扰的抗性强 于AMF, 我们预测入侵植物对AMF网络结构的影 响高于EMF网络。当然这里的预测仅仅是一些初步 的想法, 未来还需要全面和深入的实验验证。

\section{6 本地植物非菌根真菌}

外来植物入侵不仅会影响本地植物菌根真菌, 也会影响其非菌根真菌(NMF), 包括致病真菌、寄 生真菌、一些对植物可能无害的内生真菌以及在极 端环境下可以帮助植物生存的有益内生菌(Hawkes et al., 2006; Meinhardt \& Gehring, 2012; Hill et al., 2019)。有研究根据微生物之间的互作关系将本地植 物根内微生物分为两类: 促进型和拮抗型。促进型 微生物的存在能为其他微生物甚至是病原菌的侵染 提供便利条件，而拮抗型微生物不仅会抑制互惠微 生物，还会抑制致病菌的入侵(Li et al., 2019)。菌根

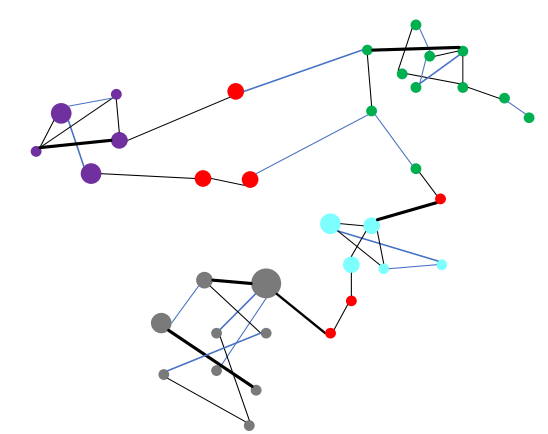

图2 菌根真菌网络结构概念图(改自 de Vries和Wallenstein (2017))。不同颜色的圆圈表示不同的模块(如不同种类的丛 枝菌根真菌), 各模块的连接点用红色圆圈表示, 线粗细表 示连接性强弱，黑线表示正相关，蓝线表示负相关。

Fig. 2 A conceptual diagram of the mycorrhizal fungal network structure (adapted from de Vries \& Wallenstein, 2017). Circles with different colors indicate different modules (i.e., different mycorrhizal fungal communities). Module connections are indicated by red circles. Thicker lines indicate stronger mycorrhizal fungi connections. The black lines indicate positive correlations, and the blue lines indicate negative correlations.

真菌与 NMF之间也存在拮抗关系(Bufford et al., 2019; Sarkar et al., 2019)。例如，根中AMF侵染增加 会使NMF的侵染下降(Maherali \& Klironomos, 2007; Liang et al., 2015; Barnes et al., 2018); EMF也能有 效抵抗病原菌的侵染(Chen et al., 2019)。

Hawkes等(2006)发现, 外来植物旱雀麦(Bromus tectorum)入侵使两种本地植物的AMF丰富度降 低, 而NMF所占比例增加。如果这些NMF属于致病 菌, 那么旱雀麦入侵将使本地植物的生长受到双重 抑制: 一是AMF丰富度减少带来植物养分吸收的降 低; 二是致病真菌所占比例增加对植物的危害 (Meinhardt \& Gehring, 2012)。这说明入侵植物可以 通过影响本地植物 NMF间接影响菌根真菌与本地 植物生长间的关系(图3)。因此, 入侵植物不仅可以 直接影响本地植物菌根真菌的组成和丰富度等, 还 可以通过改变NMF中有益真菌与有害真菌的组成 或/和比例, 进而间接影响本地植物菌根真菌的侵 染率、菌根内部真菌结构、根外菌丝、真菌群落组 成及真菌网络等(图3)。在研究入侵植物对本地植物 菌根真菌影响时, 我们应充分考虑到 NMF的变化, 并查明这些NMF的“身份” (致病真菌、寄生真菌、 无害真菌, 还是有益真菌)。

\section{2 入侵植物影响本地植物菌根真菌的机制}

\section{1 生态机制}

入侵植物可以通过多种生态机制影响本地植物 


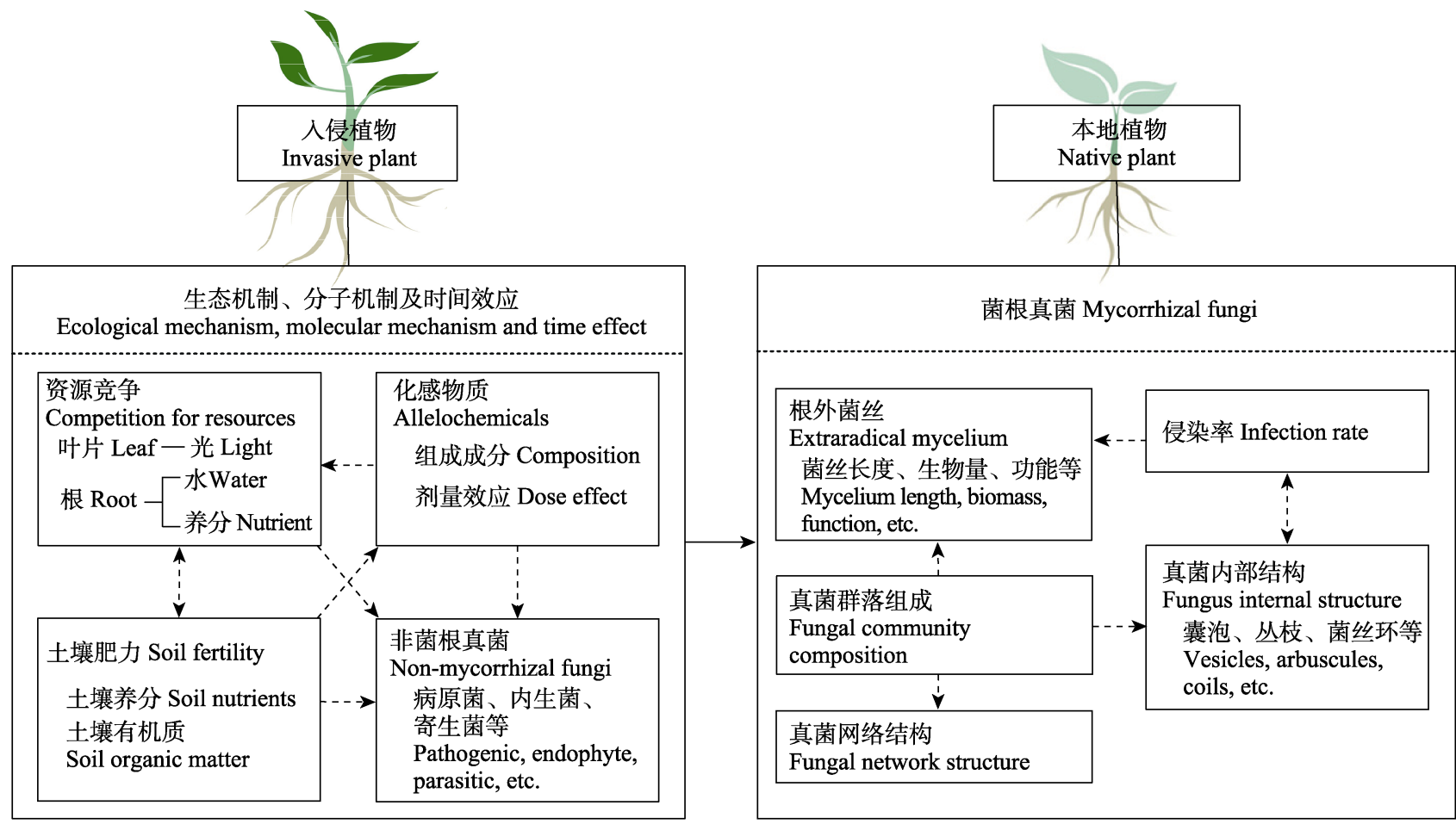

图3 外来入侵植物对本地植物菌根真菌影响的概念图(改自Grove等(2017a))。实线箭头表示改变; 虚线箭头表示存在未知的 关系。

Fig. 3 Conceptual illustration showing how invasive plants affect the symbiotic mycorrhizal fungi in native plant roots (adapted from Grove et al., 2017a). Solid arrows indicate change; dotted arrows indicate possible relationships.

的菌根真菌(Grove et al., 2017a), 目前国内外相关 研究主要集中在物种竞争、土壤养分变化和化感作 用3个方面。如表2所示, 入侵植物往往具有较强的 资源(光和养分等)竞争能力。例如, Solanum carolinense 有着强大的无性繁殖能力可以快速扩散(魏 雪苹等, 2020)。入侵植物还可以抑制本地植物光合 作用(Funk \& Vitousek, 2007; van Kleunen et al., 2010; Huang et al., 2020), 光合产物的减少可能会 抑制本地植物菌根真菌侵染(Fellbaum et al., 2012) (图3)。入侵植物往往具有较强的养分竞争力和大量 的根系分泌物(Liao et al., 2008; Grove et al., 2017b; 韩雪等, 2020; Huang et al., 2020)(表2)。入侵植物还 可以通过调落物和根系分泌物等改善和提高土壤养 分(Zhang et al., 2018b; Pérez Castro et al., 2019), 形 成植物和土壤之间的正反馈(Zhang et al., 2018c, 2020; Zhao et al., 2019, 2020), 进而降低本地植物 (如Solidago decurrens和Andropogon gerardii) 菌根真 菌的侵染率, 改变菌根真菌的群落组成(陆建忠等, 2005; Johnson et al., 2010)(图3)。入侵植物还可以通 过化感作用对本地植物菌根真菌产生直接影响 (Thorpe et al., 2009; Soudzilovskaia et al., 2015)(图
3)。入侵植物产生的化感物质(如类黄酮和芥子油苷 等)能抑制菌根真菌孢子萌发、生长和侵染，从而抑 制依赖这些真菌的本地植物的生长(Callaway \& Aschehoug, 2000; Callaway \& Ridenour, 2004; Prati \& Bossdorf, 2004; Callaway et al., 2008)。这些化感 物质也可能通过抑制本地植物的生长(Zheng et al., 2015), 从而降低植物对菌根真菌碳的供应, 进而抑 制菌根真菌侵染。此外, 外来植物所分泌的化感物 质可能也会影响本地植物的非菌根真菌, 进而对本 地植物菌根真菌产生间接影响(图3)。实际上, 本地 植物菌根真菌的变化可能是多种机制共同作用的结 果(Grove et al., 2017a, 2017b)。不同入侵植物对本地 植物菌根真菌的影响机制可能不同，而不同本地植 物菌根真菌对每种机制的响应可能也有差异，这使 得不同外来植物入侵对不同本地植物菌根真菌的影 响可能呈现出不同的趋势。

\section{2 分子机制}

植物与菌根真菌形成共生关系是一个复杂的 信号转导过程。目前已经证实，从枝菌根的形成始 于根系与AMF之间的信号交流(Gutjahr \& Parniske, 2013; Tian et al., 2019)。首先, 根系(如, 莲刺参 
表2 外来植物入侵的生态机制

Table 2 Ecological mechanisms of alien plant invasion

\begin{tabular}{lll}
\hline 生态机制 & 举例 & 参考文献 \\
Mechanism of ecology & Example & Reference \\
\hline
\end{tabular}

物种竞争

Species competition

与农作物(如高粱(Sorghum bicolor)、玉米(Zea mays))相比，入侵植物Parthenium hysterophorus具有快速早期生 Bajwa et al., 长的能力。

Compared with crops (such as Sorghum bicolor and Zea mays), the invasive plant Parthenium hysterophorus can grow much more rapidly in their early stage.

比较夏威夷 19 对入侵植物和本地植物的资源利用效率, 发现入侵植物具有较高的碳同化率、光利用效率、瞬 Funk \& 时氮利用效率和瞬时能量利用效率。

Comparing the resource utilization efficiency for 19 paired invasive-native plants in Hawaii, invasive plants are 2007

observed to have higher carbon assimilation rate, light use efficiency, instantaneous nitrogen and energy use efficiency.

比较47对入侵植物和非入侵植物对草食性动物的抵抗能力及养分含量发现, 入侵植物拥有更高的叶氮含量, Huang et al., 受到食草动物的损伤较小。

Comparisons among 47 paired invasive and non-invasive plants for leaf herbivore-resistance and nutrient content show that invasive plants have higher leaf nitrogen content and less damage by herbivores.

比对125种入侵植物和196种非入侵植物的生理性状发现，入侵植物在生长率、养分分配及抗逆性更有优势。 van Kleunen Comparing physiological traits of 125 invasive with plants 196 non-invasive plants show that invasive plants have et al., 2010 more advantages in growth rate, nutrient allocation and stress resistance.

外来植物Solanum carolinense 具有较强的抗寒能力和无性繁殖能力。

Wei et al.,

Exotic plant, Solanum carolinense, has strong ability for cold resistance and asexual reproduction.

2020

气候变暖及氮沉降的增加可以增强入侵植物Solidago canadensis叶片的资源获取能力。

Zhou et al.

Climate warming and increased nitrogen deposition can enhance leaf resource acquisition of an invasive plant, 2019

Solidago canadensis.

化感物质

Allelochemical

土壤养分变化 Soil nutrient variation
入侵植物白羊草(Bothriochloa ischaemum)的渗滤液抑制本地植物 Andropogon gerardii 和 Schizachyrium Greer et al scoparium发芽及生长。

The leachate of an invasive plant, Bothriochloa ischaemum, inhibits germination and growth of the native plants, Andropogon gerardii and Schizachyrium scoparium.

入侵植物水烛(Typha angustifolia)根系分泌的酚类物质抑制了本地植物Bolboschoenus fluviatilis的生长发育。 Jarchow \& Phenolic compounds secreted by roots of an invasive plant, Typha angustifolia, inhibit growth and development of a Cook, 2009 native plant, Bolboschoenus fluviatilis.

Solidago canadensis入侵分泌的化感物质抑制了本地植物莴苣(Lactuca sativa)种子萌发和幼苗生长。 Hu et al., Allelochemicals secreted by the invasion of Solidago canadensis inhibit seed germination and seedling growth of a 2020 native plant, Lactuca sativa.

外来植物Solanum carolinense 含有龙葵碱及草酸盐结晶。

The exotic plant Solanum carolinense contains solanine and oxalate crystals.

Wei et al.,

Parthenium hysterophorus可以分泌帕台单宁、咖啡酸、香草酸等化感物质帮助自身入侵。

Shi \&

Parthenium hysterophorus can secrete parthenin, caffeic acid, vanillic acid and other allelochemicals to facilitate its Adkins, invasion.

2018

氮沉降会增强S. canadensis入侵初期分泌的化感物质对本地植物莫亘种子萌发和幼苗生长的抑制程度。 Hu et al., Nitrogen deposition can enhance the inhibition of the allelochemicals secreted by S. canadensis at its initial invasive 2020 stage on seed germination and seedling growth of a native plant, Lactuca sativa.

分析94篇文章发现，入侵植物增大了植物、土壤和土壤微生物中的碳和氮库大小。

Liao et al., Analysis of 94 published papers show that invasive plants increase the size of carbon and nitrogen pools in plants, 2008 soils and soil microorganisms.

与本地植物 Artemisia californica、Salvia mellifera、Salvia apiana、锦鸡儿 (Calochortus splendens) 和 Pérez Castro Dichelostemma capitatum相比, 外来植物Centaurea stoebe、Hirschfeldia incana和Bromus madritensis可以通过et al., 2019 加快调落物分解改善土壤养分。

Compared with native plants such as Artemisia californica, Salvia mellifera, Salvia apiana, Calochortus splendens and Dichelostemma capitatum, exotic plants, like Centaurea stoebe, Hirschfeldia incana and Bromus madritensis, can increase soil nutrient level by increasing litter decomposition.

入侵植物Mikania micrantha分泌的化感物质绿原酸和 $\beta$-石竹烯加快了土壤有机氮的矿化过程。

Allelochemicals secreted by the invasive plant, Mikania micrantha, such as chlorogenic acid and $\beta$-caryophyllene 2020 accelerate mineralization of soil organic nitrogen.

入侵植物通过凋落物改变了根际微生物土壤群落和养分循环, 形成植物-土壤正反馈调节。 Invasive plants can form a positive plant-soil feedback via its litter decomposition which could change rhizosphere 2018c soil microbial communities and nutrient cycling.

杂草Conyza canadensis入侵的土壤中有效氮和有机质含量增加。

The content of available nitrogen and organic matter increases in the soil invaded by Conyza canadensis.

Zhang et al., 2020

与非入侵地土壤相比, Eupatorium catarium入侵后土壤氮含量提高 $4.32 \mathrm{mg} \cdot \mathrm{kg}^{-1}$ 。

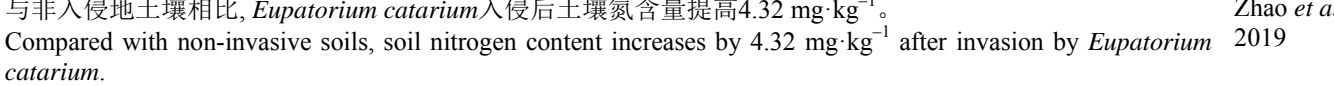

Ambrosia trifida在入侵地的土壤-植物反馈高于原产地。

Zhao et al.,

Ambrosia trifida has a greater plant-soil feedback in invaded ranges than that in its native ranges. 
(Lotus japonicus)) 分泌独脚金内酯等信号分子, 促 进AMF孢子萌发和菌丝分枝, 增加菌丝与根系接触 的概率(Akiyama et al., 2005)。之后, 从枝菌根真菌 分泌多种信号分子(即菌根因子, 如LCOs、CO4/ $\mathrm{CO} 5$ 和PsMiSSP10b), 被根系相应的受体识别后激 活钙离子信号通路, 进而形成侵染线, 激活菌根真 菌的侵染过程(Maillet et al., 2011; Martin et al., 2017; Plett et al., 2020)(图4)。例如，水稻AMF分泌脂壳寊 糖(LCOs)和短链壳葟糖(CO4/CO5)因子, 能被水稻 中 LysM 受体样激酶的异源体 (包括 OsMYR1/ OsLYK2和OsCERK1)识别(He et al., 2019)。但在豆 科植物中, $\mathrm{AMF}$ 释放的 $\mathrm{LCOs}$ 和 $\mathrm{CO} 4 / \mathrm{CO} 5$ 因子, 被 NFR1/LYK3 识别(Zhang et al., 2015)。在上述过程中, 菌根真菌除了产生小分子分泌蛋白(MiSSPs)来识别 宿主之外, 也会产生植物细胞壁分解酶(PCWDEs) (Martin et al., 2008, 2017; Kohler et al., 2015)来破坏 宿主植物的细胞壁, 为共生关系的建立扫除“障 碍”。而根与菌根真菌之间关系的核心在于两者对于 碳(脂类和糖)和养分的交换(Jiang et al., 2017), 这种 物质交换过程涉及一系列脂类合成酶以及养分转运 蛋白。例如, 丝裂原活化蛋白激酶(MAPKs) 在植物 和AMF信号沟通中起到重要作用; STR转运蛋白负 责紫花苜宿 (Medicago truncatula)中脂肪酸的转运 (Bonfante \& Genre, 2010; 田否等, 2016; Bravo et al., 2017)。入侵植物可以通过影响酶和这些转运蛋白干
扰本地植物菌根真菌侵染进而影响本地植物生长。 如Bravo等(2017)发现, 紫花苜宿根系脂质合成酶 (FatM和RAM2) 突变后, AMF的侵染率降低, 这两个 酶调控植物对菌根真菌所需脂质的供应。因此, 对 根与菌根真菌物质交换过程的影响也可能是入侵植 物干扰本地植物菌根真菌的一个重要的分子机制, 是未来研究中值得进一步关注的领域。

\section{3 入侵时间的影响}

已有研究证实外来植物的成功入侵受入侵时间 的影响(Catford et al., 2019)。在入侵植物对本地植物 菌根真菌影响的相关研究中, 大多数研究都是在某 个特定的入侵时间或入侵阶段进行的，不同入侵时 间和阶段的对比还较缺乏(Grove et al., 2017a), 更 不了解外来植物入侵对本地植物菌根真菌的影响是 否也具有时间效应。另一方面, 相关研究中入侵时 间序列的跨度较短。例如, Ruckli等(2016)比较研究 了I. glandulifera入侵 3 和 15 个月时, 本地EMF植物 青冈(Fagus sylvatica)的菌根真菌侵染率分别降低 $33 \%$ 和 $66 \%$ 。入侵植物的这种影响在一定入侵年限 之后可能会有较大改变(Lankau et al., 2009; Dostál et al., 2013)。Grove等(2017b)研究发现, 入侵植物 Cytisus scoparius对本地植物花旗松(Pseudotsuga menziesii) 菌根真菌的影响在入侵3-31年间保持稳 定。不过研究者也承认, 入侵更长时间之后

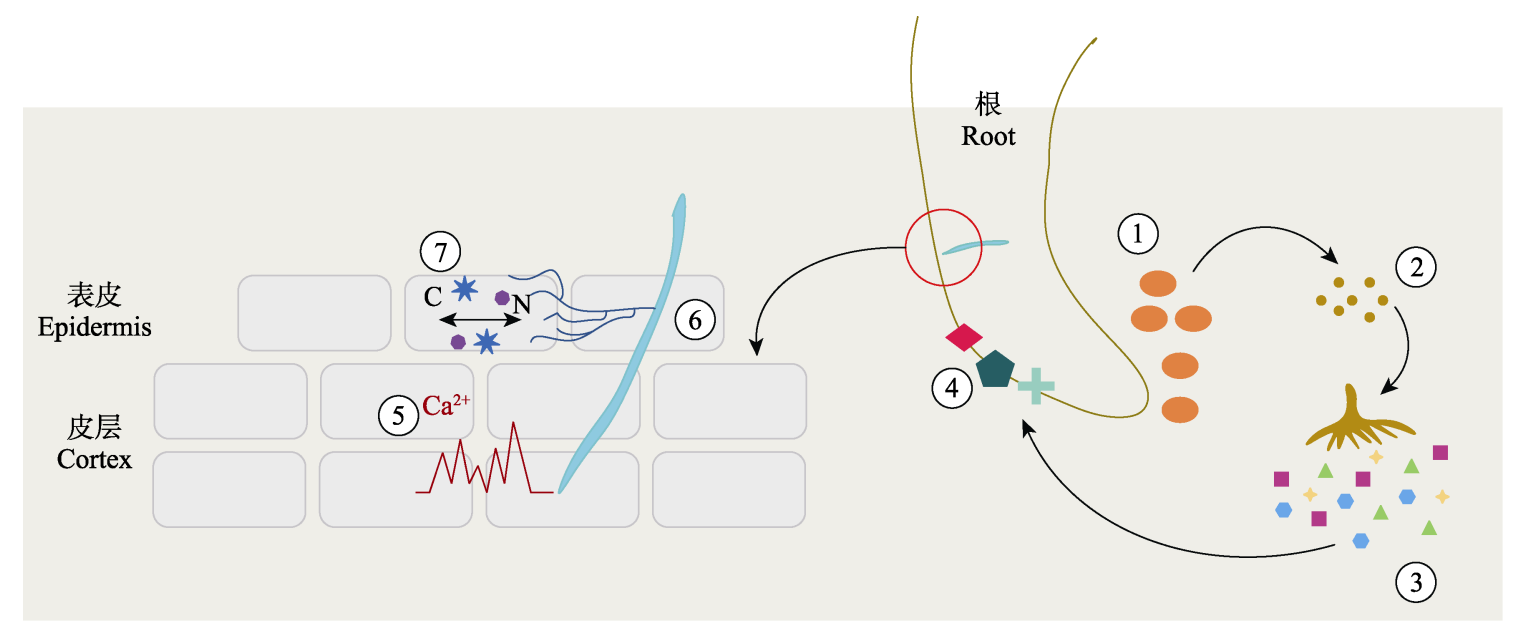

图4 植物与菌根真菌共生关系分子模式图(参考Martin等(2017))。根系分泌信号分子(1)), 促进土壤中从枝孢子((2))的萌发和 菌丝分枝; AMF分泌的菌根因子(3)被根系上的受体(4)识别并激活钲离子信号通路(5)), 进而形成侵染线(6); 菌根真菌菌 丝侵入根细胞后，与根系进行碳-养分交换，这中间涉及一系列酶和转运蛋白(7)的共同作用。

Fig. 4 Conceptual model for the symbiotic relationship between plants and mycorrhizal fungi (adapted from Martin et al., 2017). Roots secrete signaling molecules (1) promote germination of AMF spores (2) and mycelium branching in the soil; mycorrhizal factors secreted by AMF (3) are recognized by receptor proteins in root cells (4), and then activate the calcium signaling pathway (5) to initiate formation of invasion lines of the mycorrhizal fungi (6)). After that, the carbon and nutrient exchange between mycorrhizae and root cells also requires a series of enzymes and transport proteins in the root-mycorrhiza interface (7)). 
C. scoparius的这种影响也可能减弱。随着入侵时间 延长, 本地植物与土壤微生物会对入侵植物做出适 应性响应，从而消除入侵植物带来的负面影响(类 延宝等, 2010)。我们推测, 随着入侵时间的持续, 外 来植物对本地植物菌根真菌的影响会减弱, 且入侵 植物影响菌根真菌的机制, 如前述的植物竞争 (Hawkes, 2007; Yelenik \& D’Antonio, 2013)、土壤养 分(Grove et al., 2017b)及化感作用(Lankau et al., 2009; Li et al., 2017; 胡文杰等, 2020)等均会随入侵 时间的延长而发生变化, 这些变化的方向和程度的 差异, 最终可能会导致入侵的时间效应在入侵种间 出现差异。我们建议通过连年栽培入侵植物, 驯化 土壤以构建入侵时间序列 (Flory \& D'Antonio, 2015)。这种连年栽培实验, 一方面可以直接观测入 侵植物种群的长期动态; 更重要的是, 我们可以系 统地检验入侵植物对本地植物菌根真菌影响的上述 几种机制(竞争、化感以及对土壤养分的调节等)的 机制的作用及动态变化。这些研究能够为不同入侵 阶段的外来植物的防控和管理提供针对性的措施。

\section{4 展望}

外来植物通过干扰本地植物菌根真菌获得竞争 优势是一种重要的入侵机制。尽管如此, 相对于其 他入侵机理, 我们对外来植物入侵与本地植物菌根 真菌间关系的认识仍然十分匮乏(Jordan et al., 2011; Gaggini et al., 2018; 孙建茹等, 2019)。这主要表现 在: 1)目前入侵植物对本地植物菌根真菌影响的研 究结果存在较大差异。一方面可能是由于所选植物 类群有限选材范围较为狭窄 (Allsopp \& Holmes, 2001; Endresz et al., 2013; Lekberg et al., 2013); 另 一方面菌根内部结构、根外菌丝相关功能蛋白和真 菌网络结构的研究相对较少, 还无法得到普遍结论 (Toju et al., 2018; Lugli et al., 2019; Luo et al., 2019); 此外研究者们经常忽略非菌根真菌(如病原菌)在外 来植物入侵中起到的作用(Hawkes et al., 2006; 初 亚男等, 2018)。2)相对于生态机制, 入侵植物如何影 响本地植物菌根真菌与宿主根系的相互识别、侵染 及养分交换的分子机制研究较少(He et al., 2019; Stefanowicz et al., 2019)。3)我们还不清楚外来植物 长时间入侵时本地植物菌根真菌的响应 (Dombrowski et al., 2017; Grove et al., 2017b)。

此外, 我们认为在入侵植物影响本地植物菌根
真菌相关研究中, 未来还应该重点关注(但不仅仅 局限于)以下几个方面: 1)全球变化(如全球变暖、氮 沉降、干旱、火灾及虫害等)如何调节外来植物对本 地植物菌根真菌的影响, 尤其需要关注多种全球变 化因子在多个水平时的交互作用。2)同时关注入侵 植物对本地植物菌根真菌影响的多种生态机制(资 源竞争、化感作用和土壤养分调节等)和分子机制 (菌丝对土壤养分的吸收、转运以及和植物之间进行 的碳-养分交换)，以及这些机制之间的相互关系。3) 以往的研究往往局限于有限的空间范围和较短的时 间, 未来的研究更需要探究在较大的时间(十数年 甚至上百年)和空间(热带、亚热带和温带)尺度上研 究入侵植物对本地植物菌根真菌影响的变化趋势以 及相应的生态和分子机制。

致谢感谢河南农业大学引进人才启动经费 (30500854) 的资助。

\section{参考文献}

Akiyama K, Matsuzaki KI, Hayashi H (2005). Plant sesquiterpenes induce hyphal branching in arbuscular mycorrhizal fungi. Nature, 435, 824-827.

Allison SD, Nielsen C, Hughes RF (2006). Elevated enzyme activities in soils under the invasive nitrogen-fixing tree Falcataria moluccana. Soil Biology \& Biochemistry, 38, $1537-1544$.

Allsopp N, Holmes PM (2001). The impact of alien plant invasion on mycorrhizas in mountain fynbos vegetation. South African Journal of Botany, 67(2), 150-156.

Bai YF, Li M, Liu RJ, Wan FH, Guo SX (2012). Interactions effects of invasive plants Coreopsis grandiflora and associated plant Dianthus barbatus and their influences on AM fungi. Journal of Qingdao Agricultural University (Natural Science), 29(1)，1-5，14. [柏艳芳, 李敏, 刘润进, 万方 浩, 郭绍霞 (2012). 入侵植物大花金鸡菊与伴生植物须 苞石竹的互作效应及其对 AM真菌的影响. 青岛农业大 学学报(自然科学版), 29(1), 1-5, 14.]

Bajwa AA, Chauhan BS, Farooq M, Shabbir A, Adkins SW (2016). What do we really know about alien plant invasion? A review of the invasion mechanism of one of the world's worst weeds. Planta, 244, 39-57.

Baohanta R, Thioulouse J, Ramanankierana H, Prin Y, Rasolomampianina R, Baudoin E, Rakotoarimanga N, Galiana A, Randriambanona H, Lebrun M, Duponnois R (2012). Restoring native forest ecosystems after exotic tree plantation in Madagascar: combination of the local ectotrophic species Leptolena bojeriana and Uapaca bojeri mitigates the negative influence of the exotic species Eucalyptus camaldulensis and Pinus patula. Biological 
Invasions, 14, 2407-2421.

Barnes CJ, van der Gast CJ, McNamara NP, Rowe R, Bending GD (2018). Extreme rainfall affects assembly of the root-associated fungal community. New Phytologist, 220, $1172-1184$.

Barto EK, Antunes PM, Stinson K, Koch AM, Klironomos JN, Cipollini D (2011). Differences in arbuscular mycorrhizal fungal communities associated with sugar maple seedlings in and outside of invaded garlic mustard forest patches. Biological Invasions, 13, 2755-2762.

Bennett AE, Daniell TJ, Öpik M, Davison J, Moora M, Zobel M, Selosse MA, Evans D (2013). Arbuscular mycorrhizal fungal networks vary throughout the growing season and between successional stages. PLOS ONE, 8, e83241. DOI: 10.1371/journal.pone.0083241.

Bennett AE, Thomsen M, Strauss SY (2011). Multiple mechanisms enable invasive species to suppress native species. American Journal of Botany, 98, 1086-1094.

Bergmann J, Weigelt A, van der Plas, Laughlin DC, Kuyper TW, Guerrero-Ramírez N, Valverde-Barrantes OJ, Bruelheide $\mathrm{H}$, Freschet $\mathrm{GT}$, Iversen $\mathrm{CM}$, Kattge J, Luke McCormack M, Meier IC, Rillig MC, Roumet C, Semchenko M, Sweeney CJ, van Ruijven J, York LM, Mommer L (2020). The fungal collaboration gradient dominates the root economics space in plants. BioRxiv, 6, 3756. DOI: 10.1101/2020.01.17.908905.

Blossey B, Notzold R (1995). Evolution of increased competitive ability in invasive nonindigenous plants, a hypothesis. Journal of Ecology, 83, 887-889.

Bonfante P, Genre A (2010). Mechanisms underlying beneficial plant-fungus interactions in mycorrhizal symbiosis. Nature Communications, 1, 48. DOI: 10.1038/ncomms1046.

Bravo A, Brands M, Wewer V, Dörmann P, Harrison MJ (2017). Arbuscular mycorrhiza-specific enzymes FatM and RAM2 fine-tune lipid biosynthesis to promote development of arbuscular mycorrhiza. New Phytologist, 214, 1631-1645.

Brundrett MC, Tedersoo L (2018). Evolutionary history of mycorrhizal symbioses and global host plant diversity. New Phytologist, 220, 1108-1115.

Bufford JL, Hulme PE, Sikes BA, Cooper JA, Johnston PR, Duncan RP (2019). Novel interactions between alien pathogens and native plants increase plant-pathogen network connectance and decrease specialization. Journal of Ecology, 108, 750-760.

Burke DJ (2008). Effects of Alliaria petiolata (garlic mustard; Brassicaceae) on mycorrhizal colonization and community structure in three herbaceous plants in a mixed deciduous forest. American Journal of Botany, 95, 1416-1425.

Callaway RM, Aschehoug ET (2000). Invasive plants versus their new and old neighbors: a mechanism for exotic invasion. Science, 290, 521-523.

Callaway RM, Cipollini D, Barto K, Thelen GC, Hallett SG,
Prati D, Stinson K, Klironomos J (2008). Novel weapons: invasive plant suppresses fungal mutualists in America but not in its native Europe. Ecology, 89, 1043-1055.

Callaway RM, Ridenour WM (2004). Novel weapons: invasive success and the evolution of increased competitive ability. Frontiers in Ecology and the Environment, 2, 436-443.

Cantor A, Hale A, Aaron J, Traw MB, Kalisz S (2011). Low allelochemical concentrations detected in Garlic mustardinvaded forest soils inhibit fungal growth and AMF spore germination. Biological Invasions, 13, 3015-3025.

Carlson LA, McConnaughay KD, Morris SJ (2014). Effect of garlic mustard invasion on ectomycorrhizae in mature pine trees and pine seedlings//Groninger JW, Holzmueller EJ, Nielsen CK, Dey DC. Proceedings of the 19th Central Hardwood Forest Conference. Department of Agriculture, Forest Service, Northern Reaserch Station, Newtown Square, USA. 214-219.

Catford JA, Jansson R, Nilsson C (2009). Reducing redundancy in invasion ecology by integrating hypotheses into a single theoretical framework. Diversity and Distributions, 15, 22-40.

Catford JA, Smith AL, Wragg PD, Clark AT, Kosmala M, Cavender-Bares J, Reich PB, Tilman D (2019). Traits linked with species invasiveness and community invasibility vary with time, stage and indicator of invasion in a long-term grassland experiment. Ecology Letters, 22, 593-604.

Chen E, Liao H, Chen B, Peng S (2020). Arbuscular mycorrhizal fungi are a double-edged sword in plant invasion controlled by phosphorus concentration. New phytologist, 226, 295-300.

Chen L, Swenson NG, Ji NN, Mi XC, Ren HB, Guo LD, Ma KP (2019). Differential soil fungus accumulation and density dependence of trees in a subtropical forest. Science, 366, 124-128.

Chu YN, Zhang HB, Qin ZF, Gai JP (2018). Relationship of AM fungi with non-mycorrhizal plants. Chinese Journal of Applied Ecology, 29，321-326. [初亚男, 张海波, 秦泽 峰, 盖京苹 (2018). AM真菌与非菌根植物的相互作用 关系. 应用生态学报, 29, 321-326.]

de Vries FT, Griffiths RI, Bailey M, Craig H, Girlanda M, Gweon HS, Hallin S, Kaisermann A, Keith AM, Kretzschmar M, Lemanceau P, Lumini E, Mason KE, Oliver A, Ostle N, Prosser JI, Thion C, Thomson B, Bardgett RD (2018). Soil bacterial networks are less stable under drought than fungal networks. Nature Communications, 9, 3033. DOI: 10.1038/s41467-018-05516-7.

de Vries FT, Wallenstein MD (2017). Below-ground connections underlying above-ground food production: a framework for optimising ecological connections in the rhizosphere. Journal of Ecology, 105, 913-920.

Delavaux CS, Smith-Ramesh LM, Kuebbing SE (2017). Beyond nutrients, a meta-analysis of the diverse effects of 
arbuscular mycorrhizal fungi on plants and soils. Ecology, 98, 2111-2119.

Dickie IA, Bufford JL, Cobb RC, Desprez-Loustau ML, Grelet G, Hulme PE, Klironomos J, Makiola A, Nuñez MA, Pringle A, Thrall PH, Tourtellot SG, Waller L, Williams NM (2017). The emerging science of linked plant-fungal invasions. New phytologist, 215, 1314-1332.

Dombrowski N, Schlaeppi K, Agler MT, Hacquard S, Kemen E, Garrido-Oter R, Wunder J, Coupland G, Schulze-Lefert P (2017). Root microbiota dynamics of perennial Arabis alpina are dependent on soil residence time but independent of flowering time. The ISME Journal, 11, 43-55.

Dostál P, Müllerová J, Pyšek P, Pergl J, Klinerová T (2013). The impact of an invasive plant changes over time. Ecology Letters, 16, 1277-1284.

Eissenstat DM, Kucharski JM, Zadworny M, Adams TS, Koide RT (2015). Linking root traits to nutrient foraging in arbuscular mycorrhizal trees in a temperate forest. New Phytologist, 208, 114-124.

Endresz G, Somodi I, Kalapos T (2013). Arbuscular mycorrhizal colonisation of roots of grass species differing in invasiveness. Community Ecology, 14, 67-76.

Fellbaum CR, Gachomo EW, Beesetty Y, Choudhari S, Strahan GD, Pfeffer PE, Kiers ET, Bücking H (2012). Carbon availability triggers fungal nitrogen uptake and transport in arbuscular mycorrhizal symbiosis. Proceedings of the National Academy of Sciences of the United States of America, 109, 2666-2671.

Feng YL, Lei YB, Wang RF, Callaway RM, Valiente-Banuet A, Inderjit, Li YP, Zheng YL (2009). Evolutionary tradeoffs for nitrogen allocation to photosynthesis versus cell walls in an invasive plant. Proceedings of the National Academy of Sciences of the United States of America, 106, 1853-1856.

Flory SL, D'Antonio CM (2015). Taking the long view on the ecological effects of plant invasions. American Journal of Botany, 102, 817-818.

Funk JL, Vitousek PM (2007). Resource-use efficiency and plant invasion in low-resource systems. Nature, 446, 1079-1081.

Gaggini L, Rusterholz HP, Baur B (2018). The invasive plant Impatiens glandulifera affects soil fungal diversity and the bacterial community in forests. Applied Soil Ecology, 124, 335-343.

Gaggini L, Rusterholz HP, Baur B (2019). The annual invasive plant Impatiens glandulifera reduces hyphal biomass of soil fungi in deciduous forests. Fungal Ecology, 39, 242-249.

Gaya Shivega W, Aldrich-Wolfe L (2017). Native plants fare better against an introduced competitor with native microbes and lower nitrogen availability. AoB PLANTS, 9, plx004. DOI: 10.1093/aobpla/plx004.
Gornish ES, Franklin K, Rowe J, Barberán A (2020). Buffelgrass invasion and glyphosate effects on desert soil microbiome communities. Biological Invasions, 22, 2587-2597.

Greer MJ, Wilson GWT, Hickman KR, Wilson SM (2014). Experimental evidence that invasive grasses use allelopathic biochemicals as a potential mechanism for invasion: chemical warfare in nature. Plant and Soil, 385, 165-179.

Grove S, Haubensak KA, Gehring C, Parker IM (2017a). Mycorrhizae, invasions, and the temporal dynamics of mutualism disruption. Journal of Ecology, 105, 1496-1508.

Grove S, Haubensak KA, Parker IM (2012). Direct and indirect effects of allelopathy in the soil legacy of an exotic plant invasion. Plant Ecology, 213, 1869-1882.

Grove S, Parker IM, Haubensak KA (2017b). Do impacts of an invasive nitrogen-fixing shrub on Douglas-fir and its ectomycorrhizal mutualism change over time following invasion? Journal of Ecology, 105, 1687-1697.

Guo XC (2020). Effect of Invasive Plant Xanthium strumarium on Mycorrhizal Fungi and Rhizobium of Glycine max under Different Light Environments. Master degree dissertation, Shenyang Agricultural University, Shenyang. [郭小 城 (2020). 不同光环境下入侵植物瘤突苍耳对大豆菌 根真菌和根瘤菌的影响. 硕士学位论文, 沈阳农业大 学, 沈阳.]

Gutjahr C, Parniske M (2013). Cell and developmental biology of arbuscular mycorrhiza symbiosis. Annual Review of Cell and Developmental Biology, 29, 593-617.

Han X, Su JQ, Yao NN, Chen BM (2020). Advances in root foraging behavior of exotic invasive plants. Biodiversity Science, 28, 727-733. [韩雪, 苏锦权, 姚娜娜, 陈宝明 (2020). 外来入侵植物的根系受养行为研究进展. 生物 多样性, 28, 727-733.]

Hawkes CV (2007). Are invaders moving targets? The generality and persistence of advantages in size, reproduction, and enemy release in invasive plant species with time since introduction. The American Naturalist, 170, 832-843.

Hawkes CV, Belnap J, D’Antonio C, Firestone MK (2006). Arbuscular mycorrhizal assemblages in native plant roots change in the presence of invasive exotic grasses. Plant and Soil, 281, 369-380.

He JM, Zhang C, Dai HL, Liu H, Zhang XW, Yang J, Chen X, Zhu YY, Wang DP, Qi XF, Li WC, Wang ZH, An GY, Yu N, He ZH, Wang YF, Xiao YL, Zhang P, Wang ET (2019). A LysM receptor heteromer mediates perception of arbuscular mycorrhizal symbiotic signal in rice. Molecular Plant, 12, 1561-1576.

Hill PW, Broughton R, Bougoure J, Havelange W, Newsham KK, Grant H, Murphy DV, Clode P, Ramayah S, Marsden KA, Quilliam RS, Roberts P, Brown C, Read DJ, Deluca TH, Bardgett RD, Hopkins DW, Jones DL (2019). 
Angiosperm symbioses with non-mycorrhizal fungal partners enhance $\mathrm{N}$ acquisition from ancient organic matter in a warming maritime Antarctic. Ecology Letters, 22, 2111-2119.

Hu WJ, Liang QJ, He YH, Sun JF (2020). Allelopathy of Solidago canadensis with different invasion degrees under nitrogen deposition. Guihaia, 40, 1531-1539. [胡文杰, 梁 秋菊, 和昱含, 孙见凡 (2020). 氮沉降对不同入侵程度 加拿大一枝黄花化感作用的影响.广西植物, 40, 1531-1539.]

Huang K, Kong DL, Lu XR, Feng WW, Liu MC, Feng YL (2020). Lesser leaf herbivore damage and structural defense and greater nutrient concentrations for invasive alien plants: evidence from 47 pairs of invasive and non-invasive plants. Science of the Total Environment, 723, 137829. DOI: 10.1016/j.scitotenv.2020.137829.

Jarchow ME, Cook BJ (2009). Allelopathy as a mechanism for the invasion of Typha angustifolia. Plant Ecology, 204, 113-124.

Jiang Y, Wang W, Xie Q, Liu N, Liu L, Wang D, Zhang X, Yang C, Chen X, Tang D, Wang E (2017). Plants transfer lipids to sustain colonization by mutualistic mycorrhizal and parasitic fungi. Science, 356, 1172-1175.

Jiang YL, Chen XH, Miao Q, Qü B (2019). Difference in fungal communities between in roots and in rootassociated soil of nine orchids in Liaoning, China. Chinese Journal of Plant Ecology, 43, 1079-1090. [蒋玉玲, 陈旭 辉, 苗青, 曲波 (2019). 辽宁省9种兰科植物根内与根 际土壤中真菌群落结构的差异. 植物生态学报, 43, 1079-1090.]

Johnson NC, Rowland DL, Corkidi L, Egerton-Warburton LM, Allen EB (2003). Nitrogen enrichment alters mycorrhizal allocation at five mesic to semiarid grasslands. Ecology, 84, 1895-1908.

Johnson NC, Wilson GWT, Bowker MA, Wilson JA, Miller RM (2010). Resource limitation is a driver of local adaptation in mycorrhizal symbioses. Proceedings of the National Academy of Sciences of the United States of America, 107, 2093-2098.

Jordan NR, Larson DL, Huerd SC (2011). Evidence of qualitative differences between soil-occupancy effects of invasive vs. native grassland plant species. Invasive Plant Science and Management, 4, 11-21.

Ju RT, Li H, Shi ZR, Li B (2012). Progress of biological invasions research in China over the last decade. Biodiversity Science, 20, 581-611. [鞠瑞亭, 李慧, 石正人, 李 博 (2012). 近十年中国生物入侵研究进展. 生物多样 性, 20, 581-611.]

Kiers ET, Duhamel M, Beesetty Y, Mensah JA, Franken O, Verbruggen E, Fellbaum CR, Kowalchuk GA, Hart MM, Bago A, Palmer TM, West SA, Vandenkoornhuyse P, Jansa J, Bücking H (2011). Reciprocal rewards stabilize cooperation in the mycorrhizal symbiosis. Science, 333,
$880-882$.

Koch AM, Antunes PM, Kathryn Barto E, Cipollini D, Mummey DL, Klironomos JN (2011). The effects of arbuscular mycorrhizal (AM) fungal and garlic mustard introductions on native AM fungal diversity. Biological Invasions, 13, $1627-1639$.

Kohler A, Kuo A, Nagy LG, Morin E, Barry KW, Buscot F, Canbäck B, Choi C, Cichocki N, Clum A, Colpaert J, Copeland A, Costa MD, Doré J, Floudas D, et al. (2015). Convergent losses of decay mechanisms and rapid turnover of symbiosis genes in mycorrhizal mutualists. Nature Genetics, 47, 410-415.

Lankau RA, Nuzzo V, Spyreas G, Davis AS (2009). Evolutionary limits ameliorate the negative impact of an invasive plant. Proceedings of the National Academy of Sciences of the United Sates of America, 106, 15362-15367.

Lau JA, Schultheis EH (2015). When two invasion hypotheses are better than one. New Phytologist, 205, 958-960.

Lei YB, Xiao HF, Feng YL (2010). Impacts of alien plant invasions on biodiversity and evolutionary responses of native species. Biodiversity Science, 18, 622-630. [类延 宝, 肖海峰, 冯玉龙 (2010). 外来植物入侵对生物多样 性的影响及本地生物的进化响应. 生物多样性, 18, 622-630.]

Lekberg Y, Gibbons SM, Rosendahl S, Ramsey PW (2013). Severe plant invasions can increase mycorrhizal fungal abundance and diversity. The ISME Journal, 7, 1424-1433.

Li M, Wei Z, Wang J, Jousset A, Friman VP, Xu Y, Shen Q, Pommier T (2019). Facilitation promotes invasions in plant-associated microbial communities. Ecology Letters, 22, 149-158.

Li YP, Feng YL, Kang ZL, Zheng YL, Zhang JL, Chen YJ (2017). Changes in soil microbial communities due to biological invasions can reduce allelopathic effects. Journal of Applied Ecology, 54, 1281-1290.

Liang M, Liu X, Etienne RS, Huang F, Wang Y, Yu S (2015). Arbuscular mycorrhizal fungi counteract the JanzenConnell effect of soil pathogens. Ecology, 96, 562-574.

Liang X, He C, Zhu X, Chen X, Lei Y, Zhang H, Qin Z, Qi X (2016). Effect of exotic Spartina alterniflora on fungal symbiosis with native plants Phragmites australis and Scirpus mariqueter, and model plants Lolium perenne L. and Trifolium repens. Aquatic Botany, 130, 50-58.

Liao C, Peng R, Luo Y, Zhou X, Wu X, Fang C, Chen J, Li B (2008). Altered ecosystem carbon and nitrogen cycles by plant invasion, a meta-analysis. New Phytologist, 177, 706-714.

Lu JZ, Qiu W, Chen JK, Li B (2005). Impact of invasive species on soil properties: Canadian goldenrod (Solidago canadensis) as a case study. Biodiversity Science, 13, 347-356. [陆建忠, 表伟, 陈家宽, 李博 (2005). 入侵种 加拿大一枝黄花对土壤特性的影响. 生物多样性, 13, 
347-356.]

Lugli LF, Andersen KM, Aragão LEOC, Cordeiro AL, Cunha HFV, Fuchslueger L, Meir P, Mercado LM, Oblitas E, Quesada CA, Rosa JS, Schaap KJ, Valverde-Barrantes O, Hartley IP (2019). Multiple phosphorus acquisition strategies adopted by fine roots in low-fertility soils in Central Amazonia. Plant and Soil, 450, 49-63.

Luo J, Meiners SJ, Carlsward BS (2019). Mycorrhizal colonization in a successional plant community. The American Midland Naturalist, 182, 12-26.

Lutgen ER, Rillig MC (2004). Influence of spotted knapweed (Centaurea maculosa) management treatments on arbuscular mycorrhizae and soil aggregation. Weed Science, $52,172-177$.

Maherali H, Klironomos JN (2007). Influence of phylogeny on fungal community assembly and ecosystem functioning. Science, 316, 1746-1748.

Maillet F, Poinsot V, André O, Puech-Pagès V, Haouy A, Gueunier M, Cromer L, Giraudet D, Formey D, Niebel A, Martinez EA, Driguez H, Bécard G, Dénarié J (2011). Fungal lipochitooligosaccharide symbiotic signals in arbuscular mycorrhiza. Nature, 469, 58-63.

Maltz MR, Bell CE, Mitrovich MJ, Iyer AR, Treseder KK (2016). Invasive plant management techniques alter arbuscular mycorrhizal fungi. Ecological Restoration, 34, 209-215.

Martin F, Aerts A, Ahrén D, Brun A, Danchin EG, Duchaussoy F, Gibon J, Kohler A, Lindquist E, Pereda V, Salamov A, Shapiro HJ, Wuyts J, Blaudez D, Buée M, et al. (2008). The genome of Laccaria bicolor provides insights into mycorrhizal symbiosis. Nature, 452, 88-92.

Martin FM, Uroz S, Barker DG (2017). Ancestral alliances: plant mutualistic symbioses with fungi and bacteria. Science, 356, eaad4501. DOI: 10.1126/science.aad4501.

Meinhardt KA, Gehring CA (2012). Disrupting mycorrhizal mutualisms, a potential mechanism by which exotic tamarisk outcompetes native cottonwoods. Ecological Applications, 22, 532-549.

Mitchell CE, Agrawal AA, Bever JD, Gilbert GS, Hufbauer RA, Klironomos JN, Maron JL, Morris WF, Parker IM, Power AG, Seabloom EW, Torchin ME, Vázquez DP (2006). Biotic interactions and plant invasions. Ecology Letters, 9, 726-740.

Mummey DL, Rillig MC (2006). The invasive plant species Centaurea maculosa alters arbuscular mycorrhizal fungal communities in the field. Plant and Soil, 288, 81-90.

Pakpour S, Klironomos J (2015). The invasive plant, Brassica nigra, degrades local mycorrhizas across a wide geographical landscape. Royal Society Open Science, 2, 150300. DOI: $10.1098 /$ rsos. 150300.

Parniske M (2008). Arbuscular mycorrhiza, the mother of plant root endosymbioses. Nature Reviews Microbiology, 6, 763-775.
Pathak R, Negi VS, Rawal RS, Bhatt ID (2019). Alien plant invasion in the Indian Himalayan Region: state of knowledge and research priorities. Biodiversity and Conservation, 28, 3073-3102.

Pattison Z, Rumble H, Tanner RA, Jin L, Gange AC (2016). Positive plant-soil feedbacks of the invasive Impatiens glandulifera and their effects on above-ground microbial communities. Weed Research, 56, 198-207.

Pérez Castro S, Cleland EE, Wagner R, Sawad RA, Lipson DA (2019). Soil microbial responses to drought and exotic plants shift carbon metabolism. The ISME Journal, 13, 1776-1787.

Plett JM, Plett KL, Wong-Bajracharya J, de Freitas Pereira M, Costa MD, Kohler A, Martin F, Anderson IC (2020). Mycorrhizal effector PaMiSSP10b alters polyamine biosynthesis in Eucalyptus root cells and promotes root colonization. New Phytologist, 228, 712-727.

Prati D, Bossdorf O (2004). Allelopathic inhibition of germination by Alliaria petiolata (Brassicaceae). American Journal of Botany, 91, 285-288.

Pringle A, Bever JD, Gardes M, Parrent JL, Rillig MC, Klironomos JN (2009). Mycorrhizal symbioses and plant invasions. Annual Review of Ecology, Evolution, and Systematics, 40, 699-715.

Richards CL, Bossdorf O, Muth NZ, Gurevitch J, Pigliucci M (2006). Jack of all trades, master of some? On the role of phenotypic plasticity in plant invasions. Ecology Letters, 9, 981-993.

Ruckli R, Rusterholz HH, Baur B (2014). Invasion of an annual exotic plant into deciduous forests suppresses arbuscular mycorrhiza symbiosis and reduces performance of sycamore maple saplings. Forest Ecology and Management, 318, 285-293.

Ruckli R, Rusterholz HP, Baur B (2016). Disrupting ectomycorrhizal symbiosis: indirect effects of an annual invasive plant on growth and survival of beech (Fagus sylvatica) saplings. Perspectives in Plant Ecology Evolution and Systematics, 19, 12-20.

Sanon A, Béguiristain T, Cébron A, Berthelin J, Ndoye I, Leyval C, Sylla S, Duponnois R (2009). Changes in soil diversity and global activities following invasions of the exotic invasive plant, Amaranthus viridis L., decrease the growth of native sahelian Acacia species. FEMS Microbiology Ecology, 70, 118-131.

Sanon A, Béguiristain T, Cébron A, Berthelin J, Sylla SN, Duponnois R (2012). Differences in nutrient availability and mycorrhizal infectivity in soils invaded by an exotic plant negatively influence the development of indigenous Acacia species. Journal of Environmental Management, 95, S275-S279.

Sarkar D, Rovenich H, Jeena G, Nizam S, Tissier A, Balcke GU, Mahdi LK, Bonkowski M, Langen G, Zuccaro A (2019). The inconspicuous gatekeeper: endophytic 
Serendipita vermifera acts as extended plant protection barrier in the rhizosphere. New Phytologist, 224, 886-901.

Sepp SK, Davison J, Jairus T, Vasar M, Moora M, Zobel M, Öpik M (2019). Non-random association patterns in a plant-mycorrhizal fungal network reveal host-symbiont specificity. Molecular Ecology, 28, 365-378.

Shannon SM, Bauer JT, Anderson WE, Reynolds HL (2014). Plant-soil feedbacks between invasive shrubs and native forest understory species lead to shifts in the abundance of mycorrhizal fungi. Plant and Soil, 382, 317-328.

Shi B, Adkins S (2018). Relative phytotoxicity of parthenium weed (Parthenium hysterophorus L.) residues on the seedling growth of a range of Australian native and introduced species. Crop and Pasture Science, 69, 837-845.

Smith SE, Read D (2008). Mycorrhizal Symbiosis. 3nd. Academic Press, New York, USA.

Soudzilovskaia NA, Douma JC, Akhmetzhanova AA, van Bodegom PM, Cornwell WK, Moens EJ, Treseder KK, Tibbett M, Wang YP, Cornelissen JHC (2015). Global patterns of plant root colonization intensity by mycorrhizal fungi explained by climate and soil chemistry. Global Ecology and Biogeography, 24, 371-382.

Stefanowicz AM, Zubek S, Stanek M, Grześ IM, Rożej-Pabijan E, Błaszkowski J, Woch MW (2019). Invasion of Rosa rugosa induced changes in soil nutrients and microbial communities of coastal sand dunes. Science of the Total Environment, 677, 340-349.

Steidinger BS, Crowther TW, Liang J, van Nuland ME, Werner GDA, Reich PB, Nabuurs GJ, de-Miguel S, Zhou M, Picard N, Herault B, Zhao X, Zhang C, Routh D, Consortium GFBI, Peay KG (2019). Climatic controls of decomposition drive the global biogeography of forest-tree symbioses. Nature, 569, 404-408.

Stinson KA, Campbell SA, Powell JR, Wolfe BE, Callaway RM, Thelen GC, Hallett SG, Prati D, Klironomos JN (2006). Invasive plant suppresses the growth of native tree seedlings by disrupting belowground mutualisms. PLOS Biology, 4, e140. DOI: 10.1371/journal.pbio.0040140.

Sun JR, Chen X, Sang XL, Meng YL, Jia YY, Zhang FJ (2019). Effects of the competition between invasive Ambrosia artemisiifolia and the native plants on species diversity of arbuscular mycorrhizal fungi. Mycosystema, 38, 1918-1929. [孙建茹, 陈雪, 桑晓玲, 蒙彦良, 贾月月, 张风娟 (2019). 入侵豚草与本地植物竞争对丛枝菌根 真菌多样性的影响. 菌物学报, 38, 1918-1929.]

Tanner RA, Gange AC (2013). The impact of two non-native plant species on native flora performance: potential implications for habitat restoration. Plant Ecology, 214, 423-432.

Tedersoo L, Bahram M, Zobel M (2020). How mycorrhizal associations drive plant population and community biology. Science, 367, eaba1223. DOI: 10.1126/science. aba1223.
Thorpe AS, Thelen GC, Diaconu A, Callaway RM (2009). Root exudate is allelopathic in invaded community but not in native community: field evidence for the novel weapons hypothesis. Journal of Ecology, 97, 641-645.

Tian H, Wang R, Li M, Dang H, Solaiman, ZM (2019). Molecular signal communication during arbuscular mycorrhizal formation induces significant transcriptional reprogramming of wheat (Triticum aestivum L.) roots. Annals of Botany, 124, 1109-1119.

Tian L, Li YJ, Tian CJ (2016). Response of arbuscular mycorrhizal fungal lipid metabolism to symbiotic signals in mycorrhiza. Acta Microbiologica Sinica, 56, 26-34. [田 磊, 李元敬, 田春杰 (2016). 丛枝菌根真菌脂类代谢对 共生信号调控的响应和反馈. 微生物学报, 56, 26-34.]

Toju H, Sato H, Yamamoto S, Tanabe AS (2018). Structural diversity across arbuscular mycorrhizal, ectomycorrhizal, and endophytic plant-fungus networks. BMC Plant Biology, 18, 292.

Trautwig AN, Eckhardt LG, Loewenstein NJ, Hoeksema JD, Carter EA, Nadel RL (2017). Cogongrass (Imperata cylindrica) affects above- and belowground processes in commercial loblolly pine (Pinus taeda) stands. Forest Science, 63, 10-16.

van Kleunen M, Dawson W, Essl F, Pergl J, Winter M, Weber E, Kreft H, Weigelt P, Kartesz J, Nishino M, Antonova LA, Barcelona JF, Cabezas FJ, Cárdenas D, Cárdenas-Toro J, et al. (2015). Global exchange and accumulation of non-native plants. Nature, 525, 100-103.

van Kleunen M, Weber E, Fischer M (2010). A meta-analysis of trait differences between invasive and non-invasive plant species. Ecology Letters, 13, 235-245.

Vogelsang KM, Bever JD (2009). Mycorrhizal densities decline in association with nonnative plants and contribute to plant invasion. Ecology, 90, 399-407.

Wan FH, Xie BY, Yang GQ (2011). Invasion Biology. Science Press, Beijing. [万方浩, 谢丙炎, 杨国庆 (2011). 入侵 生物学. 科学出版社, 北京.]

Wan J, Zhang Z, Wang C (2019). Effects of ecoregional vulnerability on habitat suitability of invasive alien plants, an assessment using 13 species on a global scale. Environmental Earth Sciences, 78, 180. DOI: 10.1007/ s12665-019-8186-3.

Wei XP, Yu J, Gao TG, Zhang BG, Zhang Z (2020). First report and eradication of an invasive weed, Solanum carolinense L., in Beijing. Plant Quarantine, 34(3), 61-63. [魏雪苹, 于晶, 高天刚, 张本刚, 张昭 (2020). 入侵性 杂草北美刺龙葵在北京市的首次发现及防除. 植物检 疫, 34(3), 61-63.]

Wilson GWT, Hickman KR, Williamson MM (2012). Invasive warm-season grasses reduce mycorrhizal root colonization and biomass production of native prairie grasses. Mycorrhiza, 22, 327-336.

Wolfe BE, Rodgers VL, Stinson KA, Pringle A (2008). The 
invasive plant Alliaria petiolata (garlic mustard) inhibits ectomycorrhizal fungi in its introduced range. Journal of Ecology, 96, 777-783.

Xi H (2019). Soil Carbon Sequestration Mediated by Arbuscular Mycorrhiza Under Stimulated Nitrogen Deposition. Master degree dissertation, Lanzhou University, Lanzhou. [席浩 (2019). 模拟氮沉降情境下丛枝菌根介导的土壤 碳固持研究. 硕士学士论文, 兰州大学, 兰州.]

Xiao LM (2018). Diversity of Microbial Community in Rhizosphere Soils of Lycium barbarum L. and Influence of Arbuscular Mycorrhizal Fungi Salt Tolerance. Master degree dissertation, Northwest A\&F University, Yangling, Shaanxi. [肖龙敏 (2018). 宁夏枸杞根际微生物群落多 样性及丛枝菌根真菌对其耐盐性的影响. 硕士学位论 文，西北农林科技大学，陕西杨凌.]

Yang K, Sun JR, Wang Y, Du EW, Meng YL, Sang XL, Zhang FJ (2019). Effects of invasive plants interacting with native plants on colonization of arbuscular mycorrhizal fungi. Mycosystema, 38, 1938-1947. [杨康, 孙建茹, 王 妍, 杜鄂嵬, 蒙彦良, 桑晓玲, 张风娟 (2019). 入侵植 物与本地植物互作对从枝菌根真菌AMF侵染率的影响. 菌物学报, 38, 1938-1947.]

Yang SQ, Zhang Q, Song XQ, Wang J, Li YD, Xu H, Guo SY, Ding Q (2019). Structural features of root-associated fungus-plant interaction networks in the tropical montane rain forest of Jianfengling, China. Biodiversity Science, 27, 314-326. [杨思琪, 张琪, 宋希强, 王健, 李意德, 许涵, 郭守玉, 丁琼 (2019). 尖峰岭热带山地雨林根部真菌植物互作网络结构特征. 生物多样性, 27, 314-326.]

Yelenik SG, D'Antonio CM (2013). Self-reinforcing impacts of plant invasions change over time. Nature, 503, 517-520.

Yu HX, Pang JF, Zhang XY, Gao L, Peng CL, Li WH (2020). Effects of two allelochemicals in alien invasive plant Mikania micrantha on soil nitrogen cycling. Journal of Tropical and Subtropical Botany, 28, 292-300. [余涵霞, 庞锦峰, 张所宇, 高雷, 彭长连, 李伟华 (2020). 外来 入侵植物薇甘菊的 2 种化感物质对土壤氮循环的影响. 热带亚热带植物学报, 28, 292-300.]

Zhang F, Li QC, Chen F, Xu H, Inderjit, Wan F (2017). Arbuscular mycorrhizal fungi facilitate growth and competitive ability of an exotic species Flaveria bidentis. Soil Biology \& Biochemistry, 115, 275-284.

Zhang FJ, Li Q, Yerger EH, Chen X, Shi Q, Wan FH (2018a). AM fungi facilitate the competitive growth of two invasive plant species, Ambrosia artemisiifolia and Bidens pilosa. Mycorrhiza, 28, 703-715.

Zhang GH, Peng SL, Li GY, Li QF (2009). Recent advances in the interaction between invasive plants and belowground ecosystem. Chinese Agricultural Science Bulletin, 25(14), 246-251. [张桂花, 彭少麟, 李光义, 李勤奋 (2009). 外 来入侵植物与地下生态系统相互影响的研究进展. 中 国农学通报, 25(14), 246-251.]
Zhang HY (2019). Effects of Invasive Plants on Mycorrhizal fungi Colonization and Its Mechanisms in Native Plants. Master degree dissertation, Shenyang Agricultural University, Shenyang. [张海艳 (2019). 入侵植物对本地 植物菌根真菌侵染及机制的影响. 硕士学位论文, 沈阳 农业大学, 沈阳.]

Zhang HY, Goncalves P, Copeland E, Qi SS, Dai ZC, Li GL, Wang CY, Du DL, Thomas T (2020). Invasion by the weed Conyza canadensis alters soil nutrient supply and shifts microbiota structure. Soil Biology \& Biochemistry, 143, 107739. DOI: 10.1016/j.soilbio.2020.107739.

Zhang L, Feng G, Declerck S (2018b). Signal beyond nutrient, fructose, exuded by an arbuscular mycorrhizal fungus triggers phytate mineralization by a phosphate solubilizing bacterium. The ISME Journal, 12, 2339-2351.

Zhang P, Li B, Wu JH, Hu SJ (2018c). Invasive plants differentially affect soil biota through litter and rhizosphere pathways: a meta-analysis. Ecology Letters, 22, 200-210.

Zhang X, Dong W, Sun J, Feng F, Deng Y, He Z, Oldroyd GE, Wang E (2015). The receptor kinase CERK1 has dual functions in symbiosis and immunity signalling. The Plant Journal, 81, 258-267.

Zhang ZL, Yuan YS, Liu Q, Yin HJ (2019). Plant nitrogen acquisition from inorganic and organic sources via root and mycelia pathways in ectomycorrhizal alpine forests. Soil Biology \& Biochemistry, 136, 107517. DOI: 10.1016/j.soilbio.2019.06.013.

Zhao MX, Lu XF, Zhao HX, Yang YF, Hale L, Gao Q, Liu WX, Guo JY, Li Q, Zhou JZ, Wan FH (2019). Ageratina adenophora invasions are associated with microbially mediated differences in biogeochemical cycles. Science of the Total Environment, 677, 47-56.

Zhao YZ, Liu MC, Feng YL, Wang D, Feng WW, Clay K, Durden LA, Lu XR, Wang S, Wei XL, Kong DL (2020). Release from below- and aboveground natural enemies contributes to invasion success of a temperate invader. Plant and Soil, 452, 19-28.

Zheng YL, Feng YL, Zhang LK, Callaway RM, Valiente-Banuet A, Luo DQ, Liao ZY, Lei YB, Barclay GF, Silva-Pereyra $C$ (2015). Integrating novel chemical weapons and evolutionarily increased competitive ability in success of a tropical invader. New Phytologist, 205, 1350-1359.

Zhou XH, Peng PH, Li JJ (2019). Simulated climate warming and nitrogen deposition influence leaf traits and leaf trait spectrum in Solidago canadensis from China and North America. Acta Ecologica Sinica, 39, 1605-1615. [周晓慧, 彭培好, 李景吉 (2019). 模拟气候变暖和氮沉降对两种 来源加拿大一枝黄花叶性状和性状谱的影响. 生态学 报, 39, 1605-1615.] 